УДК 66.017 DOI 10.36910/6775.24153966.2019.68.9

О.А. Куда, О.М. Отиченко, О.Є. Сич

Інститут проблем матеріалознавства ім. І.М. Францевича НАН Украӥни

\title{
СТРУКТУРА ТА ВЛАСТИВОСТІ МОДИФІКОВАНОЇ МЦДЮЮ КЕРАМІКИ НА ОСНОВІ БІОГЕННОГО ГІДРОКСИАПАТИТУ МЕДИЧНОГО ПРИЗНАЧЕННЯ
}

\begin{abstract}
В роботі досліджено вплив міді (1 мас. \%) на структуру та властивості трьох типів кераміки на основі

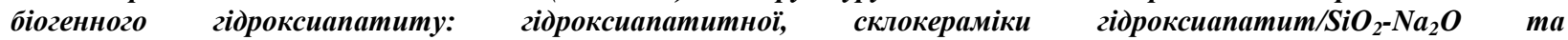
гідроксиапатит/SiO $\mathrm{S}_{2}-\mathrm{B}_{2} \mathrm{O}_{3}-\mathrm{Na}_{2} \mathrm{O}$. Встановлено, ццо введення модифікуючої добавки зменшує розмір зерна в структурі кераміки, а також позитивно впливає на властивості іп vitro, знижуючи рН та збільщуючи в 2-3,5 рази швидкість резорбції зразків у фізіологічному розчині. Дослідження адсорбційної активності показало перспективність модифікованої міддю кераміки як носї̈в лікарських засобів.

Ключові слова: кераміка, гідроксиаптит, скло, мідь, структура, пористість, властивості in vitro, адсорбиійна активність, імплантат
\end{abstract}

\section{А.А. Куда, О.Н. Отиченко, Е. Е. Сыч \\ Институт проблем материаловедения им. И.Н. Францевича НАН Украины \\ СТРУКТУРА И СВОЙСТВА МОДИФИЦИРОВАННОЙ МЕДЬЮ КЕРАМИКИ НА
ОСНОВЕ БИОГЕННОГО ГИДРОКСИАПАТИТА МЕДИЦИНСКОГО НАЗНАЧЕНИЯ}

\begin{abstract}
В работе исследовано влияние меди (1 мас. \%) на структуру и свойства трех типов керамики на основе биогенного гидроксиапатита: гидроксиапатитной, стеклокерамики гидроксиапатит/SiO $\mathrm{O}_{2}-\mathrm{Na}_{2} \mathrm{O} \quad$ u гидроксиапатит/SiO${ }_{2}-\mathrm{B}_{2} \mathrm{O}_{3}-\mathrm{Na}_{2} \mathrm{O}$. Установлено, что введение модифицирующей добавки уменьщает размер зерна в структуре керамики, а также положительно влияет на свойства іn vitro, снижая рН и увеличивая в 2-3,5 раза скорость резорбции образцов в физиологическом растворе. Исследование адсорбционной активности показало перспективность модифицированной медью керамики как носителей лекарственных средств.

Ключевые слова: керамика, гидроксиаптит, стекло, медь, структура, пористость, свойства in vitro, адсорбиионная активность, имплантат
\end{abstract}

\author{
O. Kuda, O. Otychenko, O. Sych \\ Frantsevich Institute for Problems of Materials Science of NAS of Ukraine \\ STRUCTURE AND PROPERTIES OF COPPER MODIFIED CERAMICS BASED ON \\ BIOGENIC HYDROXYAPATITE FOR MEDICAL APPLICATION
}

In the present work the effect of copper (1 wt. \%) addition on the structure and properties of three types of ceramics based on biogenic hydroxyapatite was investigated. Samples based on biogenic hydroxyapatite as well as hydroxyapatite and $\mathrm{SiO}_{2}-\mathrm{Na}_{2} \mathrm{O}$ glass were obtained at $780^{\circ} \mathrm{C}$. Samples with composition hydroxyapatite and $\mathrm{SiO}_{2}-\mathrm{B}_{2} \mathrm{O}_{3}-\mathrm{Na}_{2} \mathrm{O}$ glass were obtained by two-stage sintering at $1100^{\circ} \mathrm{C}$ and $780^{\circ} \mathrm{C}$, respectively. It was established that the addition of modified element to the ceramics allows reducing grain size in the structure of ceramics, and also ambiguously affects the porosity. In addition, the addition of copper has a positive effect on the in vitro properties of materials, reducing the $\mathrm{pH}$ and increasing the rate of absorption of the samples in saline by 2-3.5 times. According to the studies of the adsorption activity of copper-modified ceramics samples their potential as drug carriers for accelerating the treatment of bone defects in orthopedics, traumatology and dentistry has been shown.

Keywords: ceramics, hydroxyapatite, glass, copper, structure, porosity, in vitro properties, adsorption activity, implant

\section{Вступ}

На сьогоднішній день для інженерії кісткової тканини знаходять застосування різноманітні види матеріалів, такі як полімери, метали і їх сплави, кераміка, біоскло та різноманітні композити на їх основі. Щодо біокераміки, то найбільш активно використовують гідроксиапатит (ГА) як синтетичного, так і біогенного походження. Широке застосування гідроксиапатиту пояснюється його хімічною спорідненістю із кісткою та відмінними біосумісними властивостями. Біоскло, в свою чергу, забезпечує кращі механічні властивості біокераміки [1-7].

Організм людини містить величезну кількість хімічних елементів, серед яких Са, Р, О, C, H, P, S, Na, Mg, S, B, Cl, K, V, Mn, Fe, Co, Ni, Cu, Zn, Mo, Cr, Si, I, F, Se. Більшість хімічних елементів містяться в кістковій тканині та у крові. Мікроелементи $є$ життєво необхідними, оскільки при їх відсутності або нестачі порушується нормальна життєздатність організму. Ще в 70-х роках минулого століття було встановлено, що перебіг біохімічних процесів, який відбувається в кістковій тканині в умовах фізіологічної чи репаративної регенерації, а також паталогічних станах кістки, каталізується (активується) великою кількістю катіонів мікроелементів, серед яких велике значення мають мікроелементи зі змінною валентністю [8-10]. При цьому у звичайних умовах фізіологічної регенерації кістки мікроелементи відіграють важливу роль не лише в процесах відновлення кристалічної решітки гідроксиапатиту, але й тісно пов'язані 
обміном органічних компонентів кістки за рахунок прямого впливу на остеогенні клітинні елементи, сприяючи тим самим підтримці рівня їх диференціації [9].

Мідь в людському організмі бере участь у процесах кровотворення, впливає на стан кісткової, сполучної тканини та епітелію, нормалізує роботу ендокринной системи, укріплює стінки судин, підвищує імунітет і нейтралізує вільні радикали, забезпечує обмін заліза та разом 3 залізом і вітаміном C бере участь в утворенні гемоглобіну, покращує травлення, бере участь у побудові ряду ферментів і білків, підвищує ефективність лікарських препаратів, в тому числи дію антибіотиків, має протизапальну і протимікробну дію Нестача міді в організмі призводить до деструкції кровоносних судин, патологічного росту кісток, дефектів у сполучних тканинах. Крім того, вважають, що дефіцит міді служить однією з причин ракових захворювань. У деяких випадках ураження легень раком, у людей похилого віку, лікарі пов'язують із віковим зниженням вмісту міді в організмі. Однак, надлишок міді в організмі призводить до порушення психіки і паралічу деяких органів (хвороба Вільсона). Токсичною для організму вважається доза міді $>250$ мг. У невеликих дозах мідь використовують в медицині для затримки росту та розмноження бактерій: як приклад, $\mathrm{CuSO}_{4}$ застосовується при лікуванні кон'юктивіту у вигляді очних крапель (25\%-й розчин), а також для припікання при трахомі у вигляді очних олівців. При опіках шкіри фосфором проводять іiі рясне змочування 5\%-ним розчином $\mathrm{CuSO}_{4}$.

Введення міді до складу біокераміки та біоскла дозволяє покращити ангіогенез, i регенерація кісток у порівнянні з нелегованими матеріалами при їх імплантації, а також суттєво покращити антибактеріальні властивості імплантатів. Крім того, введення $\mathrm{Cu}^{2+}$ у вигляді $\mathrm{CuO} \mathrm{у}$ кількості 0,5-3,0 мас. \% до складу пористого біоскла не призводить до токсичності [7, 11-14].

Таким чином, мідь демонструє великий потенціал як багатофункціональний терапевтичний засіб для профілактики захворювань, пов'язаних з інфекціями, та для стимуляції регенерації кісток завдяки своїй антисептичній та бактерицидній дії.

Тому метою даної роботи було дослідити влив міді як модифікуючої добавки на структуру та властивості кераміки на основі біогенного гідроксиапатиту, отриманої як без, так і з додаванням рідкого натрійсилікатного та натрійборосилікатного скла.

\section{Матеріали та методи дослідження}

Для проведення досліджень було отримано шість типів зразків склокераміки на основі біогенного гідроксиапатиту (БГА) склад яких наведено в таблиці 1. Всі зразки отримували методом одностороннього пресування при тиску 100 МПа з подальшим спіканням при температурі $780{ }^{\circ} \mathrm{C}(\mathrm{T})$. Легуючу добавку у кількості 1 мас. \% для зразків типу БГА $+\mathrm{Cu}$ та ОК 015+Сu вводили до складу БГА (або суміші БГА та скла) в сухому вигляді та проводили змішування на рольгангу протягом 4 годин 3 подальшим пресуванням та спіканням зразків. Для композитів ОК6 застосовували двостадійне спікання - суміш склошихти та БГА у необхідному співвідношенні спікали при температурі $1100{ }^{\circ} \mathrm{C}\left(\mathrm{T}_{1}\right)$, потім подрібнювали до розміру частинок $<160$ мкм, додавали легуючу добавку (у випадку отримання складу ОК $6+\mathrm{Cu}$, змішували на рольгангу протягом 4 годин, формували зразки та спікали при температурі $780{ }^{\circ} \mathrm{C}(\mathrm{T})$.

Структуру одержаних зразків досліджували методом скануючої електронної мікроскопії 3 використанням мікроскопів JEOL Superprobe 733 (Японія), Hitachi S-3500N (Hitachi, Японія) та Zeiss Ultra Plus (Carl Zeiss Meditec AG, Німеччина).

Таблиия 1

Склад зразків склокераміки, режими їх термообробки та пористість після спікання

\begin{tabular}{|c|c|c|c|c|c|c|c|}
\hline \multirow{2}{*}{$\begin{array}{c}\text { Назва } \\
\text { матеріалу }\end{array}$} & \multicolumn{3}{|c|}{ Склад, мас. \% } & \multirow[t]{2}{*}{ Тип скла } & \multicolumn{2}{|c|}{$\begin{array}{l}\text { Температура } \\
\text { спікання, }{ }^{\circ} \mathrm{C}\end{array}$} & \multirow{2}{*}{$\begin{array}{c}\text { Загальна } \\
\text { пористість } \\
\quad \pm 1 \%\end{array}$} \\
\hline & БГА & скло & $\mathrm{Cu}$ & & $\mathrm{T}_{1}$ & $\mathrm{~T}$ & \\
\hline БГА & 100 & - & - & - & - & 780 & 43 \\
\hline БГА+Cu & 99 & - & 1 & - & - & 780 & 44 \\
\hline OK 015 & 85 & 15 & - & $\mathrm{SiO}_{2}-\mathrm{Na}_{2} \mathrm{O}$ & - & 780 & 49 \\
\hline OK $015+\mathrm{Cu}$ & 85 & 14 & 1 & $\mathrm{SiO}_{2}-\mathrm{Na}_{2} \mathrm{O}$ & - & 780 & 44 \\
\hline OK 6 & 50 & 50 & - & $\mathrm{SiO}_{2}-\mathrm{B}_{2} \mathrm{O}_{3}-\mathrm{Na}_{2} \mathrm{O}$ & 1100 & 780 & 21 \\
\hline $\mathrm{OK} 6+\mathrm{Cu}$ & 50 & 49 & 1 & $\mathrm{SiO}_{2}-\mathrm{B}_{2} \mathrm{O}_{3}-\mathrm{Na}_{2} \mathrm{O}$ & 1100 & 780 & 24 \\
\hline
\end{tabular}

Для прогнозування поведінки матеріалу у біологічному середовищі було використано експерименти in vitro. Як модельне середовище було використано фізіологічний розчин $0,9 \%$ $\mathrm{NaCl}$, який $є$ ізотонічним розчином рідинам живого організму. Зразки попередньо висушували в 
сушильній шафі при температурі $100^{\circ} \mathrm{C}$ протягом 2 годин, зважували на аналітичних вагах “OHAUS Pioneer PA214C” (“OHAUS Corporation”, Китай) 3 точністю 0,0001 г та поміщали у розчин, витримували 48 годин за температури $36-37^{\circ} \mathrm{C}$ в термостаті. Потім зразки виймали 3 рідини, промивали дистильованою водою та сушили при температурі $100{ }^{\circ} \mathrm{C}$ протягом 2 годин та зважували на тих же вагах. Швидкість розчинення матеріалу визначали за втратою маси протягом часу експерименту. Крім того, проводили контроль зміни рН при зануренні зразків у фізіологічний розчин з допомогою портативного рН-метру “Checker HI 98127” (“Hanna Instruments”, США).

Оцінку адсорбційної активності отриманих зразків проводили на прикладі лікарського препарату цефтріаксон, який $є$ антибіотиком III покоління цефалоспоринів широкого спектру дії для парентерального введення, що використовують при лікуванні різних захворювань, в тому числі інфекцій кісток (остеомієліту) і суглобів, для профілактики післяопераційних ускладнень. Насичення проводили розчином цефтріаксону (Ceftriaxon, «Arterium», Україна) у фізіологічному розчині («Arterium», Україна) 3 концентрацією антибіотику 40000 мг/Г відповідно до рецептурного листа на препарат. Зразки масою $\sim 0,5$ г поміщали в розчин антибіотику об'ємом 5 мл на різні проміжки часу $(0,5 ; 1,0 ; 2,0 ; 3,0 ; 4,0$ год.), після чого проводили центрифугування розчинів (центрифуга ЦЛК-1, Росія) протягом 10 хв. (частота 3000 об./хв.) 3 подальшим визначенням оптичної густини розчинів фотокалориметричним методом (ФЕК-56М, Росія).

На основі отриманих значень оптичної густини, використовуючи заздалегідь побудований калібрувальний графік, визначали залишкову масову концентрацію цефтріаксону в освітленому розчині. Адсорбційну активність визначали за формулою, мг/г:

$$
X=\frac{\left(C_{1}-C_{2} \cdot K\right) \cdot 0.025}{m},
$$

де $\mathrm{C}_{1}$ - масова концентрація вихідного розчину цефтриаксону;

$\mathrm{C}_{2}$ - масова концентрація розчину після контактування з подрібненим зразком біокераміки, $\mathrm{Mг} / л ;$

К - коефіцієнт розбавлення розчину, взятого для аналізу, після контактування з подрібненим зразком біокераміки $(K=1)$;

$\mathrm{m}$ - маса наважки подрібненого зразку біокераміки, г;

0,005 - об'єм розчину цефтріаксону, взятого для освітлення, л.

Результати та обговорення

На рис. 1 наведено зовнішній вигляд легованих міддю зразків на основі БГА. Різний характер забарвлення зразків, до яких було введено однакову кількість легуючої добавки свідчить про різні механізми модифікування кераміки та склокераміки на основі БГА. У випадку складу БГА $+\mathrm{Cu}$ спостерігаємо світло-коричневе забарвлення зразків, що може бути пов'язано 3 утворенням оксиду міді $\mathrm{CuO}$ (для якого характерне саме коричневе забарвлення) при спіканні зразків. Для ОК015+Cu, до складу якого входить 14 мас. \% скла системи $\mathrm{SiO}_{2}-\mathrm{Na}_{2} \mathrm{O}$, притаманний білий колір 3 легким відтінком блакитного. Зразки складу ОК $6+\mathrm{Cu}$ мають яскраве блакитне забарвлення, яке, на нашу думку, пов'язано з взаємодією легуючої добавки зі склом системи $\mathrm{SiO}_{2}-$ $\mathrm{B}_{2} \mathrm{O}_{3}-\mathrm{Na}_{2} \mathrm{O} .3$ практики скловаріння відомо, що в окисному середовищі мідь у кількості 1-2 \% забарвлює силікатне скло, що містить оксид натрію, в блакитний колір.

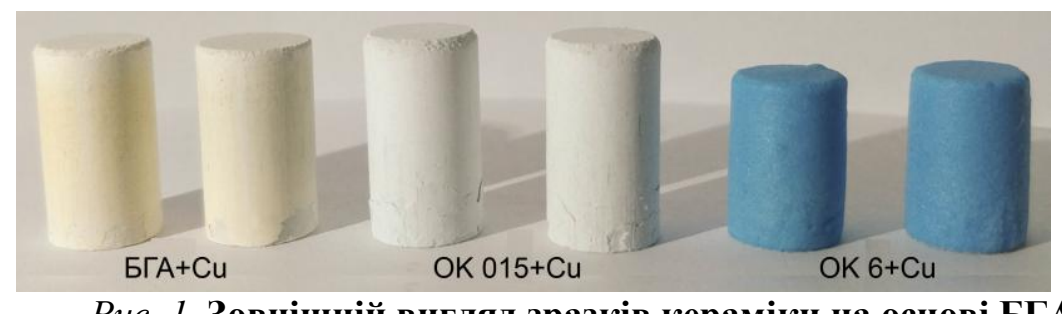

Рис. 1. Зовнішній вигляд зразків кераміки на основі БГА

Всі отримані зразки є пористими, причому вплив легуючої добавки на пористість зразків $є$ неоднозначним. Відповідно до отриманих результатів, наведених в таблиці 1 , у випадку додавання міді до БГА загальна пористість практично не змінюється та становить 43-44 \%. У випадку ж склокерамічних зразків спостерігаємо наступне: при застосуванні скла системи $\mathrm{SiO}_{2}-\mathrm{Na}_{2} \mathrm{O}$ та методу одностадійного спікання введення легуючої добавки призводить до зменшення пористості зразків від 49 до $44 \%$, а при використанні скла системи $\mathrm{SiO}_{2}-\mathrm{B}_{2} \mathrm{O}_{3}-\mathrm{Na}_{2} \mathrm{O}$ та методу двостадійного спікання додавання міді збільшує пористість від 21 до $24 \%$, що може бути пов'язано 3 особливостями спікання зразків в присутності скла різного складу. 
На рис. 2 наведено мікроструктуру на прикладі зламів отриманих зразків. 3 наведених фотознімків видно, що для складів БГА та ОК 015 характерною є рихла структура, утворена 3 частинок розмірами > 1,2 та 0,2 мкм, відповідно, які, в свою чергу, формують агломерати, 3 розвинутою відкритою мікропористістю. Для обох типів складів введення легуючої добавки у кількості 1 мас. \% приводить до зменшення розміру зерна. У випадку складу БГА при додавання міді спостерігається також трансформація форми частинок з пластівчастої в округлу. Композити ОК 6 та ОК $6+\mathrm{Cu}$ можна охарактеризувати матричною структурою, в якій натрійборосилікатна склофаза утворює «каркас», в якому знаходяться кристалічні частинки гідроксиапатиту, що формується за рахунок особливостей рідкофазного спікання матеріалу. Наявність різних пор в матеріалі ОК 6 та ОК 6+Сu пов'язано, на нашу думку, з різним характером пороутворення: пори 3 розміром 100-700 мкм утворюються за рахунок міжзернових пустот, а пори з розміром менше 100 мкм - за рахунок вспінювання скломаси при кінцевому спіканні.

Як відомо, на регенерацію кісткової тканини при імплантації матеріалу значною мірою впливає $\mathrm{pH}$ середовища організму. На рис. 3 та в таблиці 2 наведено результати дослідження зміни $\mathrm{pH}$ фізіологічного розчину при перебуванні у ньому зразків склокераміки, з яких випливає, що введення міді у кількості 1 мас. \% до складу керамічних зразків приводить до зниження $\mathrm{pH}$ модельного середовища, що $є$ позитивним фактором 3 точки зору впливу біоматеріалу на клітини живого організму. Крім того, для складу ОК 015 та ОК $015+\mathrm{Cu}$ спостерігаємо в 2,5 рази більші значення $\Delta \mathrm{pH}$ розчину, а також вищі абсолютні значення $\mathrm{pH}$ у порівнянні зі складами ОК 6 та ОК $6+\mathrm{Cu}$, що може бути пов'язано з більшою розчинністю скла системи $\mathrm{SiO}_{2}-\mathrm{Na}_{2} \mathrm{O}$, що входить до складу зразків ОК 015 та ОК $015+\mathrm{Cu}$, а також осклованістю зразків ОК 6 та ОК 6+Cu.

При подальшому перебуванні зразків у фізіологічному розчині протягом 2 діб було визначено швидкість резорбції композитів, представлену в таблиці 2. Як видно 3 наведених результатів, введення легуючої добавки підвищує швидкість резорбції обох типів композитів, в той час як склокераміка, отримана на основі БГА та натрійборосилікатного скла, має вищі показники швидкості резорбції у порівнянні зі зразками, отриманими на основі БГА та скла системи $\mathrm{SiO}_{2}-\mathrm{Na}_{2} \mathrm{O}$.
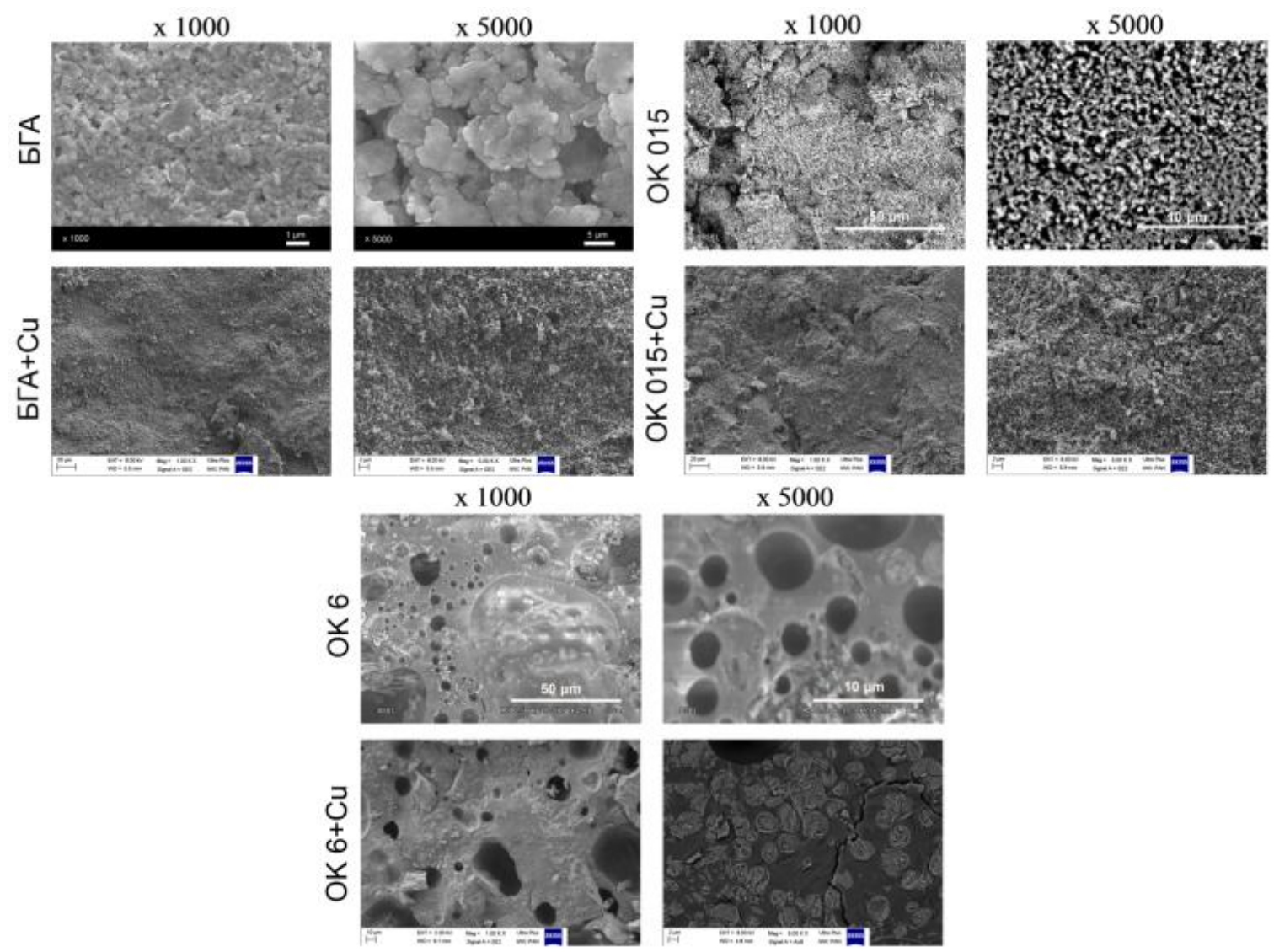

Рис.2. Мікроструктура зразків кераміки на основі БГА 


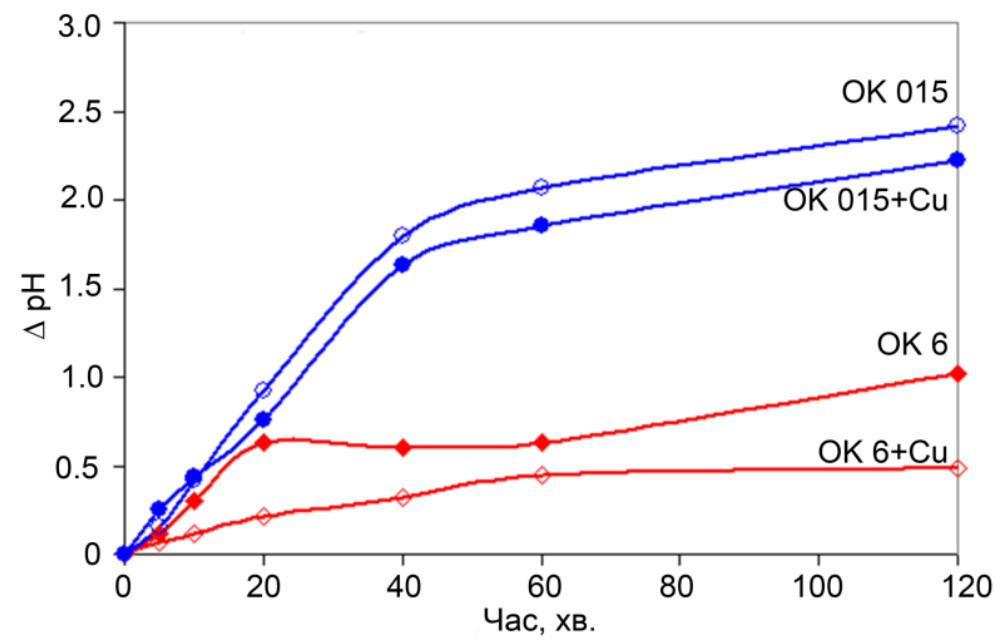

Рис. 3. Зміна рН фізіологічного розчину в присутності зразків кераміки на основі БГА

Адсорбційну активність композитів на прикладі цефтріаксону було досліджено для складів ОК 015+Cu та ОК 6+Cu. Отримані результати (рис. .4) свідчать про те, що насичення композитів антибіотиком залежить від складу застосованого скла, а також пористості отриманих зразків. Незважаючи на не, що для зразків ОК $6+\mathrm{Cu}$ характерні нижчі значення пористості, вони проявляють вищі показники адсорбційної активності.

Таблиия 2

Швидкість резорбції та рН фізіологічного розчину після 2 год. перебування в ньому зразків кераміки на основі БГА

\begin{tabular}{|c|c|c|}
\hline Назва матеріалу & $\begin{array}{c}\text { Швидкість резорбції, } \\
\text { \% мас./добу }\end{array}$ & $\begin{array}{c}\mathrm{pH} \\
\text { фізіологічного розчину }\end{array}$ \\
\hline ОК 015 & 0,09 & 8,69 \\
\hline ОК $015+\mathrm{Cu}$ & 0,18 & 8,55 \\
\hline ОК 6 & 0,13 & 7,40 \\
\hline ОК $6+\mathrm{Cu}$ & 0,50 & 6,63 \\
\hline
\end{tabular}

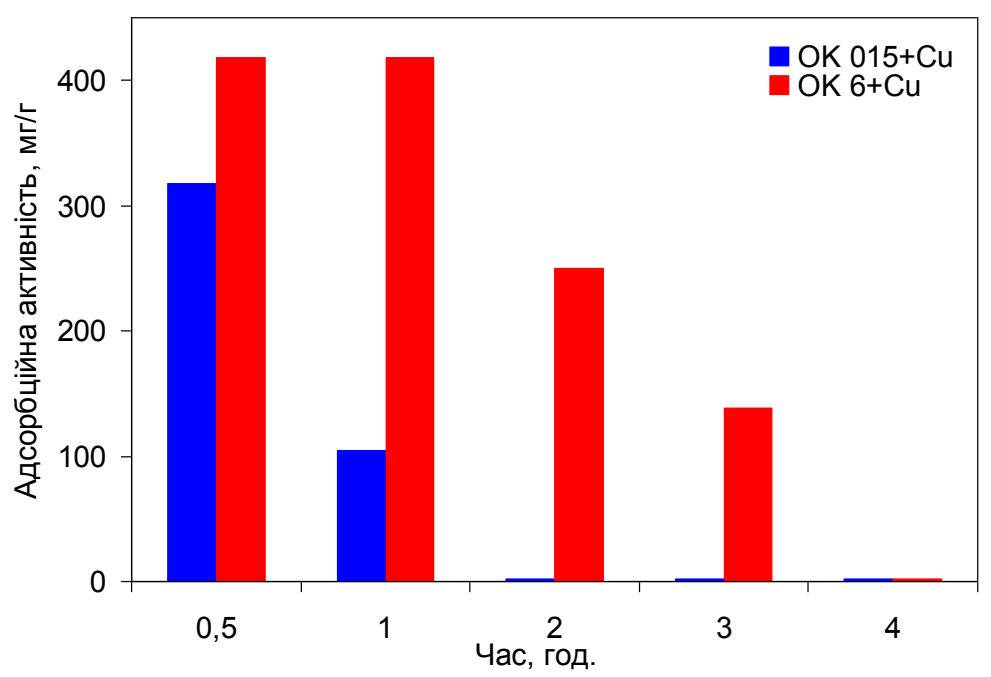

Рис. 4 Адсорбційна активність зразків кераміки на основі БГА

\section{Висновки}

Встановлено, що введення легуючої добавки сприяє зменшенню розміру зерна в структурі кераміки, а також неоднозначно впливає на пористість: у випадку додавання міді до біогенного гідроксиапатиту пористість зразків практично не змінюється та становить 43-44%. Для склокерамічних зразків, отриманих 3 застосуванням скла системи $\mathrm{SiO}_{2}-\mathrm{Na}_{2} \mathrm{O}$ та методу 
одностадійного спікання введення легуючої добавки призводить до зменшення пористості від 49 до $44 \%$, а при використанні скла системи $\mathrm{SiO}_{2}-\mathrm{B}_{2} \mathrm{O}_{3}-\mathrm{Na}_{2} \mathrm{O}$ та методу двостадійного спікання збільшує пористість від 21 до $24 \%$, що може бути пов'язано з особливостями спікання зразків в присутності скла різного складу.

Показано, що введення міді позитивно впливає на властивості in vitro, знижуючи $\mathrm{pH}$ та збільшуючи в 2-3,5 рази швидкість резорбції зразків у фізіологічному розчині. На основі досліджень адсорбційної активності модифікованих міддю зразків склокераміки показана їх перспективність як носіїв лікарських засобів для прискорення лікування дефектів кісткової тканини в ортопедії, травматології та стоматології.

Автори висловлюють щиру подяку Jan Mizeracki (Лабораторія наноструктур Інституту високих тисків Польської академії наук) за проведення структурних досліджень в рамках гранту для візитів украйнських учених на місячний термін до Польщі згідно з Протоколом до Угоди про наукове співробітництво між Польською академією наук і Національною академією наук України.

\section{Список використаних джерел:}

1. Kaur G. Mechanical properties of bioactive glasses, ceramics, glass-ceramics and composites: State-ofthe-art review and future challenges / G. Kaur, V. Kumar, F. Baino et al. // Mater. Sci. Eng. -2019. - Vol. 104. - P. 109895.

2. Ma Y. 3D printing of bioglass-reinforced $\beta$-TCP porous bioceramic scaffolds / Y. Ma, H. Dai, X. Huang et al. // J. Mater. Sci. - 2019. - Vol. 54. - P. 10437-10446.

3. Hsu P. Y. Manipulation of the degradation behavior of calcium sulfate by the addition of bioglass / P. Y. Hsu, H. C. Kuo, W. H. Tuan et al. // Prog. Biomater. - 2019. - Vol. 8. - P. 115-125.

4. Sych O. Effect of type of calcium phosphate on microstructure and properties of glass reinforced biocomosites / O. Sych, N. Pinchuk // Process. Appl. Ceram. - 2007. - Vol. 1, Issue 1-2. - P. 1-4.

5. Iatsenko A. Effect of sintering temperature on structure and properties of highly porous glass-ceramics / A. Iatsenko, O. Sych, T. Tomila // Process. Appl. Ceram. - 2015. - Vol. 9, Issue 2. P. 99-105.

6. Parkhomei O.R. Structural and mechanical properties of bioactive glass-ceramic composites / O. R. Parkhomei, N. D. Pinchuk, O. E. Sych et al. // Powder Metall. Metal Ceram. - 2016. - Vol. 55, No. 3-4. - P. 172-184.

7. Structural and chemical changes of thermally treated bone apatite. / Etok S.E., Valsami-Jones E., Wess T.J. et al. // J. Mater. Sci. - 2007. -V.42. - P. 9807-9816.

8. Барковский Е. В. Основы химии биогенных элементов / Е. В. Барковский, С. В. Ткачев - М.: Высшая школа, 2011. - 192 с.

9. Литвинова Т.Н. Биогенные элементы. Комплексные соединения / Литвинова Т. Н., Выскубова Н. К., Ненашева Л. В. - Ростов-на-Дону: Феникс, 2009. - 283 с.

10. Скоблин А.П.. Микроеэлементы в костной ткани / А. П. Скоблин, А. М. Белоус - М.: Медицина, 1968. $-232 \mathrm{c}$.

11. Radovanovi Z. Antimicrobial activity and biocompatibility of $\mathrm{Ag}^{+}$- and $\mathrm{Cu}^{2+}$ - doped biphasic hydroxyapatitetricalcium phosphate obtained from hydrothermally synthesized $\mathrm{Ag}^{+}$- and $\mathrm{Cu}^{2+}$-doped hydroxyapatite / Z. Radovanovi, B. Joki, D.Veljovi et al. // Appl. Surf. Sci.- 2014. - Vol. 307. P. 513-519.

12. Singh R. K. Synthesis, structural analysis, mechanical, antibacterial and hemolytic activity of $\mathrm{Mg}^{2+}$ and $\mathrm{Cu}^{2+}$ co-substitutions in $\beta-\mathrm{Ca}_{3}\left(\mathrm{PO}_{4}\right)_{2} /$ R. K. Singh, S. Kannan. // Mater. Sci. Eng. C. - 2014. - Vol. 45. - P. 530-538.

13. Robles-Águila M. J. Structural analysis of metal-doped ( $\mathrm{Mn}, \mathrm{Fe}, \mathrm{Co}, \mathrm{Ni}, \mathrm{Cu}, \mathrm{Zn}$ ) calcium hydroxyapatite synthetized by a sol-gel microwave-assisted method / M. J. Robles-Águila, J. A. Reyes-Avendaño, M. E. Mendoza // Ceram. Int. - 2017. - V.43. - P.12705-12709.

14. Marquesa C. F. Biocompatibility and antimicrobial activity of biphasic calcium phosphate powders doped with metal ions for regenerative medicine / C. F. Marquesa, S. Olheroa, J. C. C. Abrantes // Ceram. Int. - 2017. V.43. -P.15719-15728.

\section{Рецензенти:}

Бошицька Наталія Віталіївна, провідний науковий співробітник Інституту проблем матеріалознавства ім. І.М. Францевича НАН України, доктор технічних наук, старший науковий співробітник

Плємянніков Микола Миколайович, професор кафедри хімічної технології кераміки та скла Національного технічного університету України «Київський політехнічний інститут імені Ігоря Сікорського», кандидат технічних наук, доцент 